\title{
National COVID-19 Clinical Practice Guidelines; How it all began
}

\author{
Undugodage $\mathbf{C}^{1}$, Dissanayake $\mathrm{U}^{2}$, Tissera $\mathrm{H}^{3}$, Wijewickrama $\mathrm{A}^{4}$ \\ Journal of the Ceylon College of Physicians, 2020, 51, 63-64
}

Corona virus disease 2019, (COVID-19) is an infection caused by a novel corona virus, referred to as Severe Acute Respiratory Syndrome Corona Virus 2 (SARS-COV-2). This was first discovered in Wuhan City, Hubei Province, China and was reported to the World Health Organization (WHO) on the $31^{\text {st }}$ of December 2019 and a month later on the $30^{\text {th }}$ of January 2020, WHO declared it a Public health emergency of international concern.

As Sri Lanka watched COVID-19 unfold, there was wishful thinking on our part, with the warm weather and the eternal sunshine, we would be spared of the wrath of COVID-19. The first case in Sri Lanka was detected on the $27^{\text {th }}$ of February in a patient of Chinese nationality. Still we held on to our unwavering faith and optimism.

It was around this time that the Ceylon College of Physicians appointed a committee, to collaborate with the Epidemiology unit of the Ministry of Health $(\mathrm{MoH})$ to form the "Clinical practice guideline on COVID-19". The clinical practice guideline committee comprised of relevant specialties and thus included, physicians, respiratory physicians, an emergency medicine physician, an intensivist, a pediatrician, a virologist, a consultant judicial medical officer and an epidemiologist*.

We met at the epidemiology unit for the first time on the $10^{\text {th }}$ of March and we discussed the "Case definitions"; and the definitions were subsequently amended many times in keeping with the ever-changing landscape of COVID-19. As these were very early days where our experience was very limited, we used the guidance issued by the WHO and Centres for Disease Control and Prevention, USA, early releases from Wuhan and common sense. We divided areas amongst ourselves to work on and we thought time was on our side. The first Sri Lankan patient was diagnosed on $11^{\text {th }}$ of March and 2 more cases were soon to follow. The same day WHO declared COVID-19 a global pandemic.

That week, the situation escalated in the country. The schools were closed on the $13^{\text {th }}$ of March. The saga of the Royal Thomian match, a cricket match between two leading schools in Colombo led to a state of panic amongst the public. March $16^{\text {th }}$ was declared a holiday and the public were asked to work from home. We realized the guideline has to finish without much delay. What we didn't know was that 3 days later the airports would be closed and the country will initially be in a state of lockdown soon to be followed by island wide curfew. So, we met for the second time on 16th of March. We worked the entire day, going through and editing the drafts made on different sections by the members and the guideline was finally done!

We included guidance on disposition of patients and introduced the concept of a COVID triage area, which is practiced, to date. The 'COVID suspect ward' was also introduced with guidance on where to place the patient depending on the severity of the disease. The severity assessment was designed incorporating pulse, RR and measurement oxygen saturation by pulse oxymeter, so that the medical officer can assess a patient with minimal contact. We purposefully left

\footnotetext{
${ }^{1}$ Faculty of Medicine, University of Sri Jayewardenepura, ${ }^{2}$ National Hospital of Sri Lanka, ${ }^{3}$ Ministry of Health, Sri Lanka,

${ }^{4}$ National Institution of Infectious Diseases, Sri Lanka.

Correspondence: CU, e-mail: undugodage@sjp.ac.lk
}

http://orcid.org/0000-0001-9134-683X

Received 28 April 2020, accepted 12 May 2020.

This is an open-access article distributed under the terms of the Creative Commons Attribution License, which permits unrestricted use, distribution, and reproduction in any medium, provided the original author and source are credited. 
out auscultation of lungs at this point. We highlighted the importance of stabilizing the patient and giving standard care. Clinical management per se, was limited to supportive care at that point as there was no evidence of benefit with any drugs. Recommendation on specific therapy with HCQ and CQ was added later, and therefore was not a part of the first guideline. The management of critically ill patient was separately addressed.

The guideline also included guidance on the outbreak response plan for hospitals; as we felt that the hospitals should have a well-planned mechanism to prevent infection to health care workers ( $\mathrm{HCWs)}$ and other patients while providing optimal care to all patients. This was later elaborated on the manual on Hospital Preparedness by the Ministry of Health. Other chapters included lab diagnosis and infection prevention control, the latter addressed personal protective equipment, managing high risk patients (pregnancy and elderly), autopsy practice and disposal of a dead body. Maintaining welfare of the HCWs was briefly addressed.

This CPG guideline paved the way to many of the circulars and documents that were subsequently circulated by the $\mathrm{MoH}$ which were initiated and developed by some of the members in the committee. These included Screening and Management of Health Care Workers following exposure to a confirmed/ suspected case of COVID-19, Hospital preparedness for COVID-19 and Practical Manual and Management of accidental discovery of a COVID-19 patient in the hospital.
The CPG committee, which began as small group, grew to a much larger and a more resourceful group as more members joined, and was subsequently re named as the 'COVID-19 Clinical Expert Committee" ${ }^{\prime * *}$. We hope this guideline made a difference, to the COVID-19 care in Sri Lanka.

The CPG is available at www.epid.gov.lk

* The members of the CPG committee

Dr Ananda Wijewickrama, Dr Damayamthi Idampitiya, Dr Eranga Narangoda, Dr Upul Dissanayake, Dr Priyankara Jayawardena (Consultant Physicians), Dr Amitha Fernando, Dr Chandimani Undugodage, Neranjan Dissanayake (Consultant Respiratory Physicians), Indika Lanerol (Consultant Emergency Physician), Dr Manoj Edirisooriya (Consultant Intensivist), Dr Jayantha Weeraman (Consultant Paediatrician), Dr Rohitha Muthugala (Consultant Virologist), Dr Channa Perera (Consultant JMO) and Dr Hasitha Tissera (Consultant Epidemiologist and convenor).

\section{** The members of the COVID 19 Clinical Expert Committee}

Prof Asita de Silva, Dr Rajiva De Silva, Dr Upul Dissanayake, Dr Neranjan Dissanayake, Dr Amitha Fernando, Dr Rasika Gunapala, Dr Priyankara Jayawardena, Dr Malika Karunaratne, Dr Krishantha Jayasekera, Dr Indika Lanerol, Prof Neelika Malavige, Dr Suranga Manilgama, Dr Rohitha Mutugala, Prof Vasanthi Pinto, Prof Seneka Rajapakse, Dr Nalayani Rajaratnam, Dr Harsha Sathischandra, Dr Hasitha Tissera (convenor), Dr Chandimani Undugodage, Prof Chandanie Wanigathunge, Dr Ananda Wijewickrama. 